\title{
Asymbiotic germination, multiplication and development of Alatiglossum fuscopetalum (Orchidaceae) as affected by culture medium, sucrose and growth regulators
}

\author{
Wagner de Melo Ferreira', Marcelo Cardoso de Vasconcelos', Clede Cléia Neves Silva', \\ Hugo Rivas de Oliveira' ${ }^{1} \&$ Rogério Mamoru Suzuki²
}

\author{
${ }^{1}$ Núcleo de Estudos Ambientais, Universidade Federal do Tocantins. Caixa Postal 111, 77500-000, Porto Nacional, Tocantins, Brasil. \\ wmelouft@yahoo.com, mcvmicro@bol.com.br, cleide.cleia@hotmail.com, hugo_rivas@hotmail.com \\ ${ }_{2}^{2}$ Instituto de Botânica, Seção de Orquidário do Estado. Av. Miguel Stefano 3687, 04301-902, São Paulo, São Paulo, Brasil. \\ rogeriomsuzuki@yahoo.com.br
}

Recebido em 10.XI.2015

Aceito em 27.IV.2017

DOI: $10.21826 / 2446-8231201772106$

\begin{abstract}
This investigation aimed at studying the germination and initial growth of Alatiglossum fuscopetalum (Hoehne) Baptista under in vitro conditions. The effects of Murashige/Skoog (MS and $1 / 2 \mathrm{MS}$ ), Knudson (KN), and Vacin/Went (VW) culture media on the in vitro germination of $A$. fuscopetalum were analyzed. The influence of these media on the multiplication and initial growth of 90-day-old seedlings, and of different sucrose, benzyladenine $[\mathrm{BA}]$ and indole-butyric acid [AIB] concentrations on the multiplication and growth of 120-day-old plants were also evaluated. The results revealed that $1 / 2 \mathrm{MS}$ was the most appropriate medium for germination. Regarding the growth of 90 -day-old seedlings, MS provided the best outcome. The most effective medium for the multiplication and growth of 120 -day-old plants was $1 / 2 \mathrm{MS}$. Sucrose ranging from $1 \%$ to $3 \%$ favored plant growth. BA at $1 \mathrm{mg} \mathrm{L}^{-1}$ and IBA at $2 \mathrm{mg} \mathrm{L}^{-1}$ were the best growth regulator treatments for shoot proliferation and root growth, respectively.
\end{abstract}

Keywords: benzyladenine, indolebutyric acid, in vitro propagation, orchid

RESUMO - Germinação assimbiótica multiplicação e desenvolvimento de Alatiglossum fuscopetalum (Orchidaceae) influenciados pelo meio de cultura, sacarose e reguladores de crescimento. Este trabalho teve como objetivo estudar a germinação e o desenvolvimento in vitro de Alatiglossum fuscopetalum (Hoehne) Baptista. Foram avaliados os efeitos dos meios Murashige/Skoog (MS e 1/2MS), Knudson (KN), e Vacin/ Went (VW) na germinação. Analisou-se também a influência desses meios na multiplicação e crescimento de plântulas com 90 dias de idade, e de diferentes concentrações de sacarose, benziladenina [BA] e ácido indolilbutírico [AIB] na multiplicação e crescimento de plantas com 120 dias de idade. O meio $1 / 2 \mathrm{MS}$ proporcionou a maior germinabilidade. O meio MS foi superior aos demais em relação ao crescimento de plântulas de 90 dias, enquanto que o $1 \frac{1}{2} \mathrm{MS}$ foi o mais eficaz para a multiplicação e crescimento de plantas de 120 dias. Concentrações de $1 \%$ a $3 \%$ de sacarose favoreceram o crescimento. Para a proliferação de brotos e crescimento radicial os melhores tratamentos foram $1 \mathrm{mg} \mathrm{L}^{-1}$ de BA e $2 \mathrm{mg} \mathrm{L}^{-1}$ de AIB, respectivamente.

Palavras-chave: ácido indolibutírico, benziladenina, orquídea, propagação in vitro

\section{INTRODUCTION}

At present, Orchidaceae is among the most threatened families of angiosperms. In the tropics, most orchids are epiphytes and are one of the first plant species to be affected by environmental degradation (Barros \& Kerbauy 2004). One of the most important biomes in the tropical region is the Cerrado, which is considered one of the world's hotspots for biodiversity conservation (Myers et al. 2000). Orchidaceae is among the largest plant families in that biome, where terrestrial species predominate (43.5\%), followed by epiphytic species (38.7\%), and the remaining ones are lithophytic, climbing, aquatic and saprophytic (Barros et al. 2016). According to these authors, 699 orchid species are members of the phanerogamic flora of the Cerrado. Therefore, scientific research focusing on aspects related to the morphology, propagation and development of orchids native to the Cerrado are of great importance, not only to understand how these species adapt to the environmental conditions of the biome, but also to collect information which can contribute to conservation actions.

Orchids exhibit prolonged vegetative development and their seed germination under natural conditions is also slow and complex since it is often dependent on specific mycorrhizal associations. Moreover, out of the millions of seeds found in a capsule, a maximum of $5 \%$ germinate in the natural environment (Stoutamire 1964). Thus, the in vitro sowing of orchid seeds makes it possible to speed up the germination process and increase the percentage of seedlings obtained, which makes orchid propagation a commercially viable activity (Stancato \& Faria 1996).

The asymbiotic propagation of orchids is regarded as a very significant technique from the commercial and ecological points of view. Plants produced by this method are particularly interesting for programs targeting the reintroduction of native species in areas of environmental preservation. According to Ponert et al. (2013), the use of in vitro techniques for orchid propagation, especially asymbiotic 
germination, plays an irreplaceable role in their conservation. Therefore, the in vitro culture of orchid species turns out to be a valuable tool for the study of Cerrado orchids, which can certainly be used as a practical instrument to help prevent them from being included in lists of threatened species as well as to propagate them at a large-scale aiming at their reintroduction in environmentally protected areas or in areas that have been subjected to human disturbance.

Among the relevant aspects regarding in vitro orchid seed germination, those related to the mineral composition of the culture medium are still scarcely studied, considering the large number of species in the Orchidaceae family. Furthermore, according to several authors (Stewart 1989, Kauth et al. 2006, Suzuki et al. 2009, 2010, Abrão et al. 2014), the germination responses in relation to the culture medium vary greatly among species. The same reasoning can be applied to the initial growth of seedlings (Suzuki et al. 2009).

Alatiglossum fuscopetalum (Hoehne) Baptista, the species selected for the present investigation, is an epiphytic orchid endemic to Brazil and commonly found in Cerrado areas in the northern, northeastern and midwestern parts of Brazil (Barros et al. 2016). It bears small, ovoid pseudobulbs with one or two long, rigid leaves. Its inflorescence stalk originates from the base of the pseudobulbs and ranges from 65 to $75 \mathrm{~cm}$ in length. The average number of flowers per stalk is approximately 25 . Flowers, 2 to $3 \mathrm{~cm}$ in diameter, exhibit brown sepals which are smaller than the labellum. The petals are also brown. The labellum is mostly yellow, displays dark spots in its central part and is divided into three lobes; the lateral ones are small and ligular and the central one is wide, reniform, unguiculate, with emarginated margins (Docha Neto et al. 2006, Baptista \& Docha Neto 2007). A voucher specimen of this species is deposited in the Tocantins Herbarium (HTO) under record number 7,331.

Since it occurs in forests and woodlands adjacent to rivers and streams, this species has been subjected to strong environmental pressure due to the considerable decrease of its natural habitats primarily as a result of the construction of several hydroelectric dams along the Tocantins River and its tributaries. Taking into consideration what has been mentioned above, as well as the fact that few research articles have focused on the propagation and growth of Cerrado orchid species, notwithstanding their environmental importance, the present investigation aimed at studying the effects of different culture media on the germination of Alatiglossum fuscopetalum as well as the influence of various sucrose concentrations and growth regulator combinations on the initial development of this species under in vitro conditions.

\section{MATERIAL AND METHODS}

\section{Plant material}

Seeds obtained from immature fruits collected from six plants (in 2011, 2012 and 2013) growing in a shade house at the Environmental Studies Center, Federal University of Tocantins, Brazil, were used as initial plant material in the present study. After a 30-minute immersion in deionized/ autoclaved water, seeds were surface sterilized with $50 \mathrm{~mL}$ of a $15 \%(\mathrm{v} / \mathrm{v})$ commercial bleach $(2.5 \%$ active chlorine $)$ in deionized/autoclaved water solution for $10 \mathrm{~min}$., followed by three 15-minute rinses in deionized/autoclaved water. After that, seeds were inoculated onto the culture media.

\section{Culture media and growth conditions}

The effects of three culture media on in vitro germination were studied: Murashige \& Skoog (1962) used at two different macronutrient concentrations (full- and halfstrength) [MS; 1/2MS], Knudson (1946) [KN], and Vacin \& Went (1949) [VW]. All of them were supplemented with 0.4 $\mathrm{mg} \mathrm{L}^{-1}$ thiamine, $100 \mathrm{mg} \mathrm{L}^{-1}$ myo-inositol and $2 \%$ sucrose. The $\mathrm{pH}$ of the media was adjusted to $5.85 \pm 0.05$, and $0.2 \%$ Phytagel (Sigma Co., USA) was added to the media before autoclaving at $120^{\circ} \mathrm{C}$ and $105 \mathrm{kPa}$ for 15 minutes. There were eight replicates for each culture medium. Each replicate consisted of a 100-mL glass jar containing $40 \mathrm{~mL}$ of culture medium onto which $250 \mathrm{~mL}$ of an aqueous suspension of seeds (containing ca. 300 seeds) was inoculated. The cultures were kept in a growth room at $27 \pm 2^{\circ} \mathrm{C}$ under a 16-hour photoperiod provided by cool-white fluorescent lamps (Empalux, Brazil) at 30-35 $\mu \mathrm{mol} \mathrm{m} \mathrm{m}^{-2} \mathrm{~s}^{-1}$.

\section{Germination and initial development}

Germination analysis was carried out according to Suzuki et al. (2009). Seeds were considered germinated when swollen embryos (protocorm phase) were visible on the surface of the media. For each culture medium, five microscope slides per replication containing protocorms were prepared and analyzed by use of a dissecting microscope. The counts encompassed all protocorms of each slide which were gridded to help the counting procedure.

Ninety days after the onset of germination, the individuals contained in five replications per culture medium were evaluated in relation to the stages of protocorm development so that the growth index could be calculated (modified from Spoerl 1948). Four different developmental stages were considered according to Suzuki et al. (2009): stage 1 - swollen green embryos (protocorm phase); stage 2 - protocorm bearing one leaf; stage 3 protocorm bearing two or more leaves; stage 4 - protocorm with leaves and one or more roots (seedling stage). The percentages of individuals obtained at each developmental stage, for each replication, were multiplied by 1, 2, 3 and 4 (weights) according to their respective stages. The growth index of each replication was the sum of all stages of their individuals. Five microscope slides per replication containing protocorms/seedlings were prepared and analyzed by means of a dissecting microscope.

\section{Effects of culture media, sucrose and growth regulators on multiplication and growth}

The influence of the culture media listed above on the multiplication and growth of plants was also studied. After selecting the most suitable medium for seedling growth, 
the effects of different sucrose concentrations $(0,1,2,3,4$, 5 and $6 \%$ ), and of benzyladenine [BA] and indolebutyric acid [IBA] (in combinations of 0,1 and $2 \mathrm{mg} \mathrm{L}^{-1}$ ) on plant multiplication and growth were also evaluated. One hundred twenty-day-old plants of $1.5 \pm 0.3 \mathrm{~cm}$ in length, which had all roots removed, were used as explants in these experiments. There were five replicates for each treatment. Each replicate consisted of a $160-\mathrm{mL}$ glass jar with plastic cover containing five explants $(\mathrm{n}=25)$. The experimental conditions were the same as described for the germination experiment. The results were analyzed according to the following growth parameters: number of shoots and roots produced per inoculated explants, length of the longest shoot and root as well as dry matter of shoots and roots after 90 days of culture.

\section{Experimental design and statistical analysis}

A completely randomized experimental design was used in this study. Analysis of variance (ANOVA) was used to evaluate germination and growth parameters and the means were compared by the Tukey test at the 5\% probability level. Percentage results were arcsine transformed to normalize variation. The experiments were repeated three times.

\section{RESULTS AND DISCUSSION}

\section{Germination and initial development}

One of the most important aspects of in vitro culture is the correct selection of the culture medium, which will stimulate the appropriate development of the plants and, thus, should be adjusted for each species. For that reason, a number of different culture media were studied aiming at the establishment of the ideal nutrient concentrations and, consequently, better development of diverse plant species (Hoffmann et al. 1998).

The first evidence of the germination of A. fuscopetalum seeds was detected 10 days after seed inoculation on the culture media, which could be visualized by the presence of green protocorms (Fig. 1A) on the surface of the media. Epiphytic orchid protocorms, as in the case of A. fuscopetalum, are commonly green, enabling them to photosynthesize. The time required for the germination of orchid seeds varies greatly among species. Kraus et al. (2006) observed that seeds of Catasetum pileatum Rchb.f. originated protocorms 10 days after in vitro inoculation. Suzuki et al. (2010) verified that Cattleya bicolor Lindl. seeds germinated ca. 15 days after in vitro inoculation. Hadrolaelia tenebrosa (Rolfe) Chiron \& V. P. Castro seeds germinated 20 days after in vitro sowing (Suzuki et al. 2009) and seeds of Comparettia falcata Poepp. \& Endl. germinated ca. 40 days following in vitro inoculation (Manrique et al. 2005).

The data for seed germination are shown on Figure 2. Germination was detected on all culture media used, although the best results were observed on $1 \frac{1}{2} \mathrm{MS}$ (which was significantly higher $[\mathrm{P}<0.05]$ than the others) followed by MS. No significant difference was found between VW and
$\mathrm{KN}$. The choice of a specific culture medium is important for the process of germination and varies among orchid species (Suzuki et al. 2009). Seeds of Gongora quinquenervis Ruiz \& Pavón, for example, require a more complex and/ or nutrient-rich culture medium for germination, and their germinability was higher on MS (Martini et al. 2001), a contrasting result in relation to what was observed in $A$. fuscopetalum, whose germination percentage was higher on $1 / 2 \mathrm{MS}$.

Another important aspect that should be considered is the specific effect of each nutrient on the different phases of plant development. A nutrient that has a great influence on the germination of most orchid seeds is nitrogen, which in low concentrations stimulates that process and in high concentration inhibits it. Moreover, elevated concentrations of macronutrients can restrain the development of orchid embryos and seedlings, although their requirements vary by species (Arditti 1967). The results observed for A. fuscopetalum corroborate Arditti's statement since germination on MS was inhibited when compared with $1 / 2$ MS. Suzuki et al. (2009), upon studying the germination of Hadrolaelia tenebrosa, also obtained higher germinability when seeds were inoculated on $\mathrm{KN}$, which has lower nitrogen concentrations. On the other hand, Roy et al. (2011) reported that MS was more effective than KN and VW for the germination of Vanda coerulea Griff. ex Lindl. seeds.

Stewart (1989) stated that orchids can be divided into two major groups depending on their basic nutritional requirements for in vitro germination. The first group encompasses species whose seeds germinate on media with low nutrient concentrations such as KN and VW. The second group includes species that require media with higher amounts of macronutrients, such as for example MS. Scientific investigations have revealed that, in general, epiphytic orchids (as in the case of A. fuscopetalum), which naturally occur in nutrient-poor habitats, that is, oligotrophic environments, tend to exhibit better germination responses when sown on media of low nutrient composition and thus fall into the first group proposed by Stewart (1989). The results obtained in the present study showed that $A$. fuscopetalum seeds had higher germination percentages on $1 / 2 \mathrm{MS}$. This indicates that the nutritional requirements for the germination of this species are different from the orchids of its group.

Caramaschi (2001) reported that seeds of Cyrtopodium cristatum Lindl. (a terrestrial orchid native to the Cerrado) originated from fruits collected five months after pollination exhibited higher germination percentages on VW than on MS and KN, although significant differences were not detected. This author also verified that 7-month-old seeds germinated better on MS but no statistical differences were observed in relation to the other media. These results corroborate the idea that the most suitable conditions for orchid seed germination can be genus and sometimes species-specific (Arditti \& Ernst 1984) and that seed age 


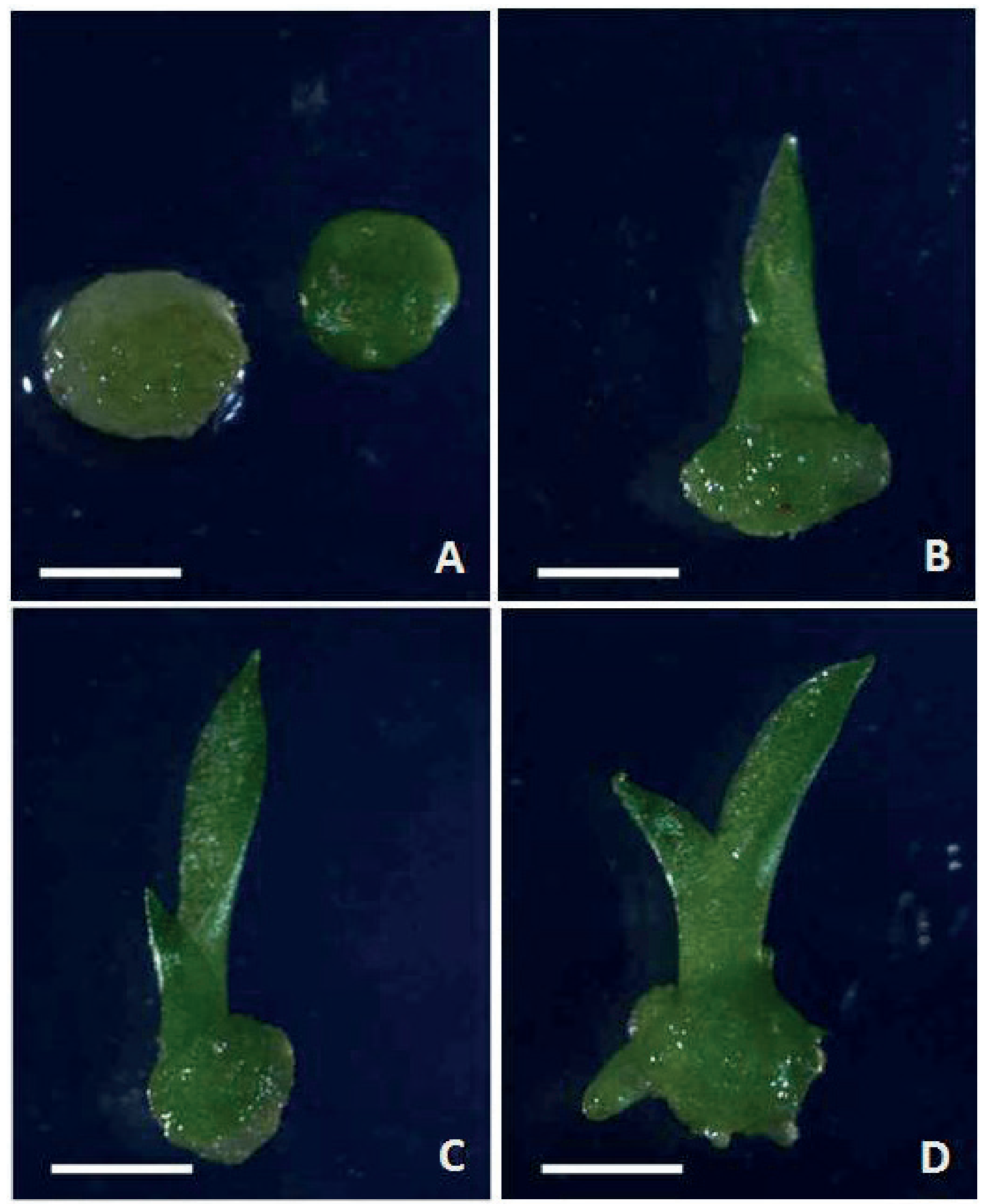

Figs. 1 A-D. Protocorm developmental stages of Alatiglossum fuscopetalum from seed germination in vitro. A. Stage 1 swollen green embryos (protocorm phase); B. Stage 2 protocorm bearing one leaf; C. Stage 3 protocorm bearing two leaves; D. Stage 4 protocorm with leaves and one root (seedling stage). Bars $=1 \mathrm{~mm}$. 
also strongly influences germination responses (Shiau et al. 2005, Suzuki et al. 2012).

It is also interesting to highlight that, in general, orchid seeds do not have endosperm, and small amounts of protein as well as lipid droplets comprise the only reserve materials found in the embryo. Lipids are used during germination and cytokinins are necessary for lipid mobilization (Manning \& Van Staden 1987). A. fuscopetalum seeds germinated on cytokinin-free media, which indicates that these seeds already have adequate levels of this hormone to support germination.

Orchids seeds are generally very small $(0.0005$ to $6 \mathrm{~mm}$ in length) and are composed of an undifferentiated embryo surrounded by a relatively transparent seed coat made up of dead cells. During germination the embryo develops into a protocorm, which later differentiates into shoots and roots thus giving origin to a seedling (George 1993, Kraus et al. 2006). Based on the formation of these structures it is possible to measure seedling development after germination by means of a growth index. Figure 1 shows the four developmental stages used to measure protocorm development of $A$. fuscopetalum from seed germination in vitro and Figure 3 displays the results obtained for the growth index on the culture media assessed. MS provided the highest growth index although it did not statistically differ from $1 / 2 \mathrm{MS}$ and $\mathrm{KN}(\mathrm{P}<0.05)$. VW was the least effective medium for this variable. Conversely, Stewart \& Kane (2006) reported that VW was the best medium for Habenaria macroceratitis Willd. since it provided the highest number of protocorms at more advanced stages of development when compared to the other culture media assessed. Suzuki et al. (2009) also verified that VW yielded the best growth index for Hadrolaelia tenebrosa. Fráguas et al. (2003), on the other hand, reported that $\mathrm{KN}$ provided the most satisfactory growth of Cattleya labiata Lindl. $x$ Laelia itambana Pabst. hybrids.

\section{Effects of culture media, sucrose and growth regulators on multiplication and growth}

Regarding the effects of the culture medium on the in vitro multiplication and growth of $A$. fuscopetalum using 120-day-old plants as explants, the highest number of shoots and roots were observed on $1 / 2 \mathrm{MS}$ (Table 1). For shoot formation no statistical difference $(\mathrm{P}<0.05)$ was detected between MS and $1 / 2 \mathrm{MS}$. KN and VW provided very similar outcomes. Upon studying the in vitro propagation of Eulophia cullenii Whight, Decruse et al. (2013) also verified that shoot proliferation was higher on diluted MS medium (1/4MS) than on the other surveyed media. Different results were reported by Duan \& Yazawa (1994) for Doriella Tiny (Doritis pulcherrima Lindl. x Kingiella philippinensis (Ames) Rolfe.). They found that the highest number of vegetative buds (which give rise to shoots) per inoculated explant was obtained on VW when compared to MS. In relation to shoot length, $1 / 2 \mathrm{MS}$ produced statistically higher results than $\mathrm{KN}$ and VW $(\mathrm{P}<0.05)$. Although longer shoots were observed on $1 / 2 \mathrm{MS}$ than on MS, no statistical

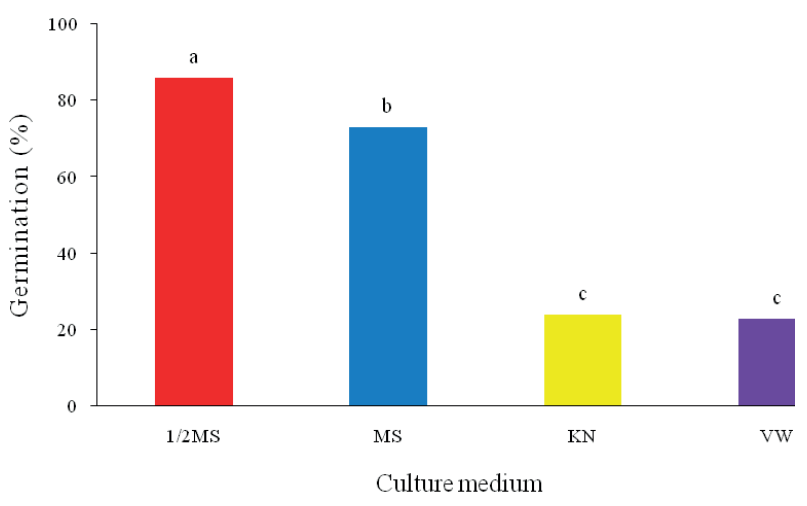

Fig. 2. Germination percentages of Alatiglossum fuscopetalum seeds on Murashige and Skoog (MS and $1 / 2 \mathrm{MS}$ ), Knudson (KN), and Vacin and Went (VW) media. Histobars with the same letters are not significantly different according to the Tukey's test at the 5\% probability level.

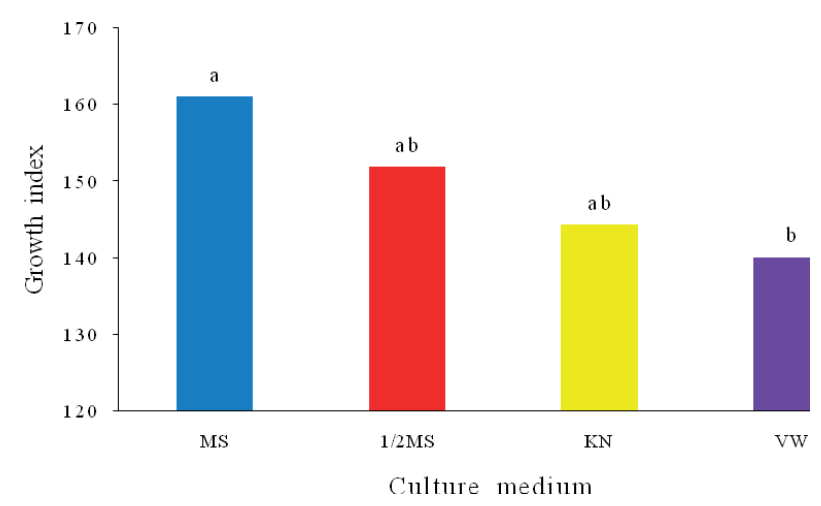

Fig. 3. Growth index of Alatiglossum fuscopetalum on Murashige and Skoog (MS and $1 / 2 \mathrm{MS}$ ), Knudson (KN), and Vacin and Went (VW) media, 90 days after the onset of seed germination. Histobars with the same letters are not significantly different according to the Tukey's test at the $5 \%$ probability level.

difference was detected between them. Decruse et al. (2013) reported that MS was statistically superior to $1 / 2 \mathrm{MS}$ and $\mathrm{KN}$ for shoot length of E. cullenii. Suzuki et al. (2009) did not find differences for shoot length in Hadrolaelia tenebrosa among MS, VW and $\mathrm{KN}$.

Considering that there are two sources of chlorine in MS, one in the form of calcium chloride and another in the form of cobalt chloride, and the latter is the only source of chlorine in VW and $\mathrm{KN}$, MS is the medium with the highest concentration of this micronutrient. It is known that chlorine is necessary for the reactions involved in the cleavage of water during photosynthesis for oxygen production. Moreover, chlorine acts as an enzyme activator during cell division, primarily in foliar tissues. Plants grown in chlorine-deficient media may exhibit reduced leaf growth (Taiz \& Zeiger 2002), which causes a decrease in photosynthesis and thus jeopardizes plant development. Therefore, it is possible that the level of chlorine in MS favored a higher multiplication rate and growth of $A$. fuscopetalum shoots, although Arditti (1967) postulated that elevated concentrations of macronutrients (as in the 
case of MS) can inhibit the development of orchid plants. It is important to mention, however, that nutrient requirements vary among species.

In terms of roots, statistical differences $(\mathrm{P}<0.05)$ were not detected among the culture media evaluated, although root formation and growth in length was more pronounced on $1 / 2 \mathrm{MS}$ and MS, respectively (Table 1). In contrast, Suzuki et al. (2009) reported that MS was detrimental to root formation in Hadrolaelia tenebrosa. Rego-Oliveira \& Faria (2005), working with Cyrtopodium paranaensis Schltr., obtained the highest number of roots in plants grown on $\mathrm{KN}$, whereas in A. fuscopetalum the worst result regarding of root formation was observed on this medium.

The results for shoot and root dry matter revealed that MS and $1 / 2$ MS provided the best outcome for these variables, respectively, although statistical differences between these two media were not detected $(\mathrm{P}<0.05)$. For Oncidium baueri Lindl., Sorace et al. (2008) reported that, in general, $1 / 2 \mathrm{MS}$ was the most effective medium for the development of this orchid in vitro, but for seedling dry matter the best result was observed on MS. Even though studies focusing on the use of different culture media have increased in number, most of them are restricted to modifications of MS and very few have addressed different orchid species. Overall, $1 / 2$ MS supported the best initial growth of seedlings and, for this reason it was selected as the basal medium for the subsequent experiments.

The effects of sucrose concentration on multiplication and growth of A. fuscopetalum 120-day-old plants are displayed in Table 2. In terms of shoot and root formation, the best treatment was 3\% sucrose. For Oncidium baueri, Sorace et al. (2008) observed that the best concentration for shoot and root production was $4 \%$ sucrose in $1 / 2 \mathrm{MS}$. In the present study, $2 \%$ and $1 \%$ sucrose provided the best results for shoot and root length, respectively. However, for $O$. baueri those authors verified that $4 \%$ sucrose was more effective for these variables. Regarding shoot dry matter, no statistical differences $(\mathrm{P}<0.05)$ were detected among treatments except when they were compared to the control (absence of sugar) which was significantly lower. Nevertheless, 2\% sucrose yielded the best result. For root dry matter 3\% sucrose was the most effective concentration although it showed no significant difference from $2 \%$ $(\mathrm{P}<0.05)$. Concentrations above $3 \%$ were inhibitory to root formation. Rego-Oliveira et al. (2003) reported that in Oncidium varicosum Lindl. 6\% sucrose was the best treatment for all variables analyzed: plant height, root formation and length, pseudobulb diameter and fresh matter. Moreira et al. (2007), upon studying the effects of different sucrose concentrations on Laelia purpurata Lindl var. venosa X Cattleya warneri T. Moore alba, stated that $2 \%$ sucrose was the best treatment for most variables and supported satisfactory plant growth. Dignart et al. (2009) demonstrated that in Cattleya walkeriana Gard. 3\% sucrose provided the best results for most variables studied.

The effects of different combinations of BA and IBA on the multiplication and growth of A. fuscopetalum 120-dayold plants (Table 3 ) revealed that $1 \mathrm{mg} \mathrm{L}^{-1} \mathrm{BA}$ alone was the best treatment $(\mathrm{P}<0.05)$ for shoot formation. In Vanda coerulea, Roy et al. (2011) verified that $0.85 \mathrm{mg} \mathrm{L}^{-1} \mathrm{BA}$ favored shoot formation and that the addition of $1 \mathrm{mg} \mathrm{L}^{-1}$ of the auxin naphthaleneacetic acid (NAA) together with this BA concentration did not alter shoot production. Hossain et al. (2010) reported that in Cymbidium giganteum Wall.

Table 1. Effects of Murashige and Skoog (MS and $1 / 2 \mathrm{MS}$ ), Knudson (KN), and Vacin and Went (VW) media on the in vitro multiplication and growth of Alatiglossum fuscopetalum 120-day-old plants. *Values followed by the same letter (lines) are not significantly different according to the Tukey's test at the $5 \%$ probability level.

\begin{tabular}{lcccc}
\hline \multirow{2}{*}{ Variable } & \multicolumn{3}{c}{ Culture Medium } \\
\cline { 2 - 5 } & $\mathrm{MS}$ & $1 / 2 \mathrm{MS}$ & $\mathrm{KN}$ & $\mathrm{VW}$ \\
\hline Number of shoots/explant & $6.4 \mathrm{ab}$ & $8.0 \mathrm{a}$ & $3.8 \mathrm{~b}$ & $3.2 \mathrm{~b}$ \\
Longest shoot length & $1.55 \mathrm{ab}$ & $1.64 \mathrm{a}$ & $1.26 \mathrm{~b}$ & $1.31 \mathrm{~b}$ \\
Number of roots/explant & $21.0 \mathrm{a}$ & $34.0 \mathrm{a}$ & $20.0 \mathrm{a}$ & $20.2 \mathrm{a}$ \\
Longest root length & $6.99 \mathrm{a}$ & $6.87 \mathrm{a}$ & $6.83 \mathrm{a}$ & $6.12 \mathrm{a}$ \\
Shoot dry matter $(\mathrm{g})$ & $0.186 \mathrm{a}$ & $0.146 \mathrm{ab} \mathrm{ab}$ & $0.067 \mathrm{~b}$ & $0.089 \mathrm{~b} \mathrm{bc}$ \\
Root dry matter $(\mathrm{g})$ & $0.076 \mathrm{a}$ & $0.087 \mathrm{a}$ & $0.021 \mathrm{~b}$ & $0.037 \mathrm{~b} \mathrm{~b}$ \\
\hline
\end{tabular}

Table 2. Effects of different sucrose concentrations on the in vitro multiplication and growth of Alatiglossum fuscopetalum 120 -day-old plants. NS $=$ number of shoots/explant; $\mathrm{SL}=$ longest shoot length; $\mathrm{NR}=$ number of roots; RL = longest root length; SDM = shoot dry matter; RDM = root dry matter *Values followed by the same letter (lines) are not significantly different according to the Tukey's test at the 5\% probability level.

\begin{tabular}{lcccccc}
\hline Sucrose $(\%)$ & NS & SL $(\mathrm{cm})$ & NR & RL $(\mathrm{cm})$ & SDM $(\mathrm{g})$ \\
\hline 0 & $1.2 \mathrm{~d}^{*}$ & $1.200 \mathrm{~b}$ & $1.2 \mathrm{~d}$ & $1.380 \mathrm{~d}$ & $0.025 \mathrm{~b}$ \\
1 & $7.0 \mathrm{abc}$ & $1.620 \mathrm{a}$ & $13.6 \mathrm{ab}$ & $6.180 \mathrm{a}$ & $0.0066 \mathrm{c}$ & $0.102 \mathrm{a}$ \\
2 & $7.8 \mathrm{ab}$ & $1.660 \mathrm{a}$ & $14.2 \mathrm{ab}$ & $4.780 \mathrm{bc}$ & $0.164 \mathrm{a}$ \\
3 & $9.0 \mathrm{a}$ & $1.120 \mathrm{ab}$ & $24.0 \mathrm{a}$ & $5.340 \mathrm{ab}$ & $0.127 \mathrm{a}$ & $0.0374 \mathrm{a}$ \\
4 & $3.4 \mathrm{~cd}$ & $0.940 \mathrm{~b}$ & $5.6 \mathrm{bc}$ & $3.160 \mathrm{~cd}$ & $0.0386 \mathrm{a}$ & $0.0156 \mathrm{~b}$ \\
5 & $4.4 \mathrm{bc}$ & $1.500 \mathrm{ab}$ & $6.2 \mathrm{bc}$ & $2.000 \mathrm{~d}$ & $0.140 \mathrm{a}$ \\
6 & $2.0 \mathrm{~d}$ & $1.140 \mathrm{ab}$ & $6.4 \mathrm{~d}$ & $1.240 \mathrm{~d}$ & $0.127 \mathrm{a}$ \\
\hline
\end{tabular}


ex Lindl. the greatest production of stem buds, which in turn, originate shoots, was obtained when $2 \mathrm{mg} \mathrm{L}^{-1} \mathrm{BA}$ together with $2 \mathrm{mg} \mathrm{L}^{-1}$ NAA were added to the culture medium. In Oncidium tigrinum Llave \& Lex., $1 \mathrm{mg} \mathrm{L}^{-1}$ BA in combination with $0.1 \mathrm{mg} \mathrm{L}^{-1} \mathrm{NAA}$ was the best treatment for shoot proliferation (Rosas \& Garcia 2011). A. fuscopetalum also responded positively to the presence of a cytokinin together with an auxin, although at higher BA concentrations; however shoot formation was inhibited when compared to $1 \mathrm{mg} \mathrm{L}^{-1} \mathrm{BA}$ alone. These results show that orchid species exhibit varied sensitivity to different hormone concentrations in the culture medium. In general, the presence of an auxin, up to a certain limit, is favorable to shoot formation, and in some cases the simultaneous addition of an auxin and a cytokinin can favor that process. It is necessary to mention that in the present study the addition of growth regulators was only tested in the presence of $2 \%$ sucrose.

In terms of shoot length (Table 3), $2 \mathrm{mg} \mathrm{L}^{-1}$ IBA promoted a significant increase $(\mathrm{P}<0.05)$ in this variable and the presence of BA inhibited it. This result corroborates the fact that auxins stimulate cell expansion and cause an increase in organ length. Souto et al. (2010) also affirmed that the presence of an auxin was advantageous for shoot length in Cattleya bicolor. Contrasting results were reported by Diaz \& Alvarez (2009) for Encyclia mariae (Ames) Hoehne, by Roy et al. (2011) for Vanda coerulea, and by Rosas \& Garcia (2011) for Oncidium tigrinum. These authors verified that relatively high BA concentrations in the presence of auxins favored shoot growth in length.

For root formation and length the best treatment was also $2 \mathrm{mg} \mathrm{L}^{-1} \mathrm{IBA}$. This finding is in agreement with the classical role of auxins in inducing root formation as well as cell expansion, which causes longitudinal growth. It was also observed that the presence of BA was inhibitory to both variables. In Vanda coerulea, BA did not inhibit root formation (Roy et al. 2011). In Cattleya bicolor, Souto et al. (2010) also described the positive effects of auxin on root formation, although at high concentrations it hindered that process. Soares (2012) reported that the presence of BA stimulated root formation and root growth in length in Dendrobium nobile Lindl. This author also confirms the fact that increases in root length are beneficial to plants since they can explore larger substrate areas and thus absorb nutrients necessary for their development.

Regarding shoot and root dry matter, $1 \mathrm{mg} \mathrm{L}^{-1}$ and $2 \mathrm{mg} \mathrm{L}^{-1}$ IBA were the most favorable concentrations, respectively, although statistical differences $(\mathrm{P}<0.05)$ were not detected between these two concentrations for both variables. The other treatments were inhibitory when compared to these two concentrations. Souto et al. (2010) reported that $0.5 \mathrm{mg} \mathrm{L}^{-1} \mathrm{NAA}$ was the most effective treatment for shoot dry matter accumulation in Cattleya bicolor and that higher concentrations were unfavorable. Those authors also observed an increase in root dry matter at NAA concentrations up to $1 \mathrm{mg} \mathrm{L}^{-1}$. It is important to emphasize that root number and size as well as the amount of dry matter accumulated by this organ are essential for the survival of orchid plants produced in vitro during the acclimatization phase.

The results presented herein revealed that among the assessed culture media $1 / 2 \mathrm{MS}$ was the most suitable for germination of $A$. fuscopetalum seeds. Regarding the growth index 90 days after germination, significant differences were not detected among MS, $1 / 2 \mathrm{MS}$ and $\mathrm{KN}$, although MS provided the highest index.

The most effective medium for the growth of 120-dayold plants was $1 / 2 \mathrm{MS}$. Sucrose at concentrations ranging from $1 \%$ to $3 \%$ favored the most prominent growth of $A$. fuscopetalum plants. BA at $1 \mathrm{mg} \mathrm{L}^{-1}$ was the best growth regulator treatment for shoot proliferation while $2 \mathrm{mg} \mathrm{L}^{-1}$ IBA provided the best results in terms of root growth.

Based on these findings, it is recommended that $1 / 2 \mathrm{MS}$ supplemented with $2 \%$ sucrose be used for germination of A. fuscopetalum seeds. After 120 days plants should be transferred to $1 / 2 \mathrm{MS}$ enriched with $3 \%$ sucrose. For shoot proliferation, the addition of $1 \mathrm{mg} \mathrm{L}^{-1} \mathrm{BA}$ to this culture medium is suggested. When the production of plants aiming at commercialization or transfer to the natural environment is intended, shoots should be cultivated in medium containing $2 \mathrm{mg} \mathrm{L}^{-1}$ IBA for root proliferation and growth before acclimatization. It is important to highlight that success in the use of in vitro techniques is dependent on a better understanding of the species'

Table 3. Effects of benzyladenine (BA) and indolebutyric acid (IBA) on the in vitro multiplication and growth of Alatiglossum fuscopetalum 120-day-old plants. $\mathrm{NS}=$ number of shoots/explant; $\mathrm{SL}=$ longest shoot length; $\mathrm{NR}=$ number of roots; $\mathrm{RL}=$ longest root length; $\mathrm{SDM}=$ shoot dry matter; $\mathrm{RDM}=$ root dry matter Values followed by the same letter (columns) are not significantly different according to the Tukey's test at the $5 \%$ probability level.

\begin{tabular}{lcccccc}
\hline $\begin{array}{l}\text { BA/IBA } \\
\left(\mathrm{mg} \mathrm{L}^{-1}\right)\end{array}$ & NS & SL $(\mathrm{cm})$ & NR & RL $(\mathrm{cm})$ & SDM (g) & RDM (g) \\
\hline $0 / 0$ & $1.93 \mathrm{c}$ & $1.55 \mathrm{~b}$ & $1.21 \mathrm{~b}$ & $0.832 \mathrm{~d}$ & $0.018 \mathrm{c}$ & $0.004 \mathrm{c}$ \\
$0 / 1$ & $3.25 \mathrm{~b}$ & $1.63 \mathrm{~b}$ & $13.33 \mathrm{ab}$ & $2.636 \mathrm{~b}$ & $0.150 \mathrm{a}$ & $0.019 \mathrm{a}$ \\
$0 / 2$ & $3.66 \mathrm{~b}$ & $1.98 \mathrm{a}$ & $16.50 \mathrm{a}$ & $5.254 \mathrm{a}$ & $0.135 \mathrm{a}$ & $0.021 \mathrm{a}$ \\
$1 / 0$ & $5.29 \mathrm{a}$ & $1.50 \mathrm{~b}$ & $1.07 \mathrm{~b}$ & $1.230 \mathrm{c}$ & $0.115 \mathrm{~b}$ & $0.012 \mathrm{~b}$ \\
$1 / 1$ & $1.96 \mathrm{c}$ & $1.47 \mathrm{~b}$ & $1.36 \mathrm{~b}$ & $0.600 \mathrm{~d}$ & $0.113 \mathrm{~b}$ & $0.011 \mathrm{~b}$ \\
$1 / 2$ & $3.43 \mathrm{~b}$ & $1.65 \mathrm{~b}$ & $1.29 \mathrm{~b}$ & $0.410 \mathrm{~d}$ & $0.110 \mathrm{~b}$ & $0.011 \mathrm{~b}$ \\
$2 / 0$ & $1.36 \mathrm{c}$ & $1.41 \mathrm{~b}$ & $0.85 \mathrm{~b}$ & $0.258 \mathrm{e}$ & $0.106 \mathrm{~b}$ & $0.011 \mathrm{~b}$ \\
$2 / 1$ & $3.88 \mathrm{~b}$ & $1.45 \mathrm{~b}$ & $0.85 \mathrm{~b}$ & $0.187 \mathrm{e}$ & $0.113 \mathrm{~b}$ & $0.012 \mathrm{~b}$ \\
$2 / 2$ & $3.14 \mathrm{~b}$ & $1.58 \mathrm{~b}$ & $0.48 \mathrm{c}$ & $0.256 \mathrm{e}$ & $0.111 \mathrm{~b}$ & $0.012 \mathrm{~b}$ \\
\hline
\end{tabular}


nutritional requirements. Therefore, the gathering of this kind of information is of great value for optimizing the in vitro propagation and growth of $A$. fuscopetalum as well as of other orchid species.

\section{ACKNOWLEDGEMENTS}

The authors thank Fundação Banco do Brasil for financial support and the Federal University of Tocantins for a research grant awarded to the first author.

\section{REFERENCES}

Abrão, M.C.R., Jorge, J., Pescador, R., Ferreira, W.M. \& Suzuki, R.M. 2014. Germinação de sementes e desenvolvimento in vitro de plântulas de Cattleya loddigesii Lindl. (Orchidaceae). Revista Brasileira de Biociências 12(3): 141-147.

Arditti, J. 1967. Factors affecting the germination of orchid seeds. Botanical Review 33: 1-97.

Arditti, J. \& Ernest, R. 1984. Physiology of germinating orchid seeds. In Orchid Biology: Reviews and Perspectives III (J. Arditti, ed.). Cornell University Press, New York, p. 178-222.

Baptista, D.H. \& Docha Neto, A. 2007. Alatiglossum Baptista (Orchidaceae) revisited. Selbyana 28(1): 1-4.

Barros, F. \& Kerbauy, G.B. 2004. Orquidologia Sul-Americana: uma compilação científica. Secretaria do Meio Ambiente, São Paulo. 192 p.

Barros, F., Vinhos, F., Rodrigues, V.T.; Barberena, F.F.V.A., Fraga, C.N., Pessoa, E.M., Forster, W., Menini Neto, L., Furtado, S.G., Nardy, C., Azevedo, C.O. \& Guimarães, L.R.S. 2016. Orchidaceae. In Lista de Espécies da Flora do Brasil. Available at: http://floradobrasil. jbrj.gov.br/jabot/floradobrasil/FB179. Accessed on 14 June, 2016.

Caramaschi, G.M.C.L. 2001. Propagação in vitro de Cyrtopodium spp. (Orchidaceae). Dissertação 110f. Universidade de Brasília, Brasília.

Decruse, S.W., Reny, N., Shylajakumari, S. \& Krishnan, P.N. 2013 In vitro propagation and field establishment of Eulophia cullenii (Wight) Bl., a critically endangered orchid of Western Ghats, India through culture of seeds and axenic seedling-derived rhizomes. In Vitro Cellular and Developmental Biology - Plant 49(5): 520-528.

Diaz, M.S.S. \& Alvarez, C.C. 2009. Plant regeneration through direct shoot formation from leaf cultures and from protocorm-like bodies derived from callus of Encyclia mariae (Orchidaceae), a threatened Mexican orchid. In Vitro Cellular and Developmental Biology Plant 45: 162-170.

Dignart, S.L., Castro, M.E., Pasqual, M., Ferronato, A., Braga, F.T. \& Paiva, R. 2009. Luz natural e concentrações de sacarose no cultivo in vitro de Cattleya walkeriana. Ciência e Agrotecnologia 33(3): 780-787.

Docha Neto, A., Baptista, D.H. \& Campacci, M.A. 2006. Coletâneas de Orquídeas Brasileiras 3: Novos Gêneros (baseados em Oncidium). Editora Brasil Orquídeas, São Paulo. 95 p.

Duan, J.X. \& Yazawa S. 1994. Induction of floral development in x Doriella Tiny (Doritis pulcherrima x Kingiella philippinensis). Scientia Horticulturae 59(3-4): 253-264.

Fráguas, C.B., Villa, F., Souza, A.V., Pasqual, M. \& Dutra, L.F. 2003. Crescimento in vitro de plântulas de orquídea oriundas da hibridação entre Cattleya labiata e Laelia itambana. Revista Ceres 50 (292): 719-726.

George, E.F. 1993. Plant propagation by tissue culture Part 2. Exegetics, Edington. $1361 \mathrm{p}$.

Hoffmann, A., Pasqual, M., Carvalho, G.R., Chalfun, N.N.J. \& Ramos, J.D. 1998. Cultura de Tecidos - Tecnologia e Aplicações: Aplicações na Propagação de Plantas. Universidade Federal de Lavras/Fundação de Apoio ao Ensino, Pesquisa e Extensão, Lavras. 130 p.

Hossain, M.M., Sharma, M., Silva, J.A.T. \& Pathak, P. 2010. Seed germination and tissue culture of Cymbidium giganteum Wall. ex Lindl. Scientia Horticulturae 123(4):479-487.

Kauth, P.J., Vendrame, W.A. \& Kane, M.E. 2006. In vitro seed culture and seedling development of Calopogon tuberosus. Plant Cell Tissue and Organ Culture 85:91-102.
Knudson, L. 1946. A new nutrient solution for germination of orchid seeds. American Orchid Society Bulletin 15(5): 214-217.

Kraus, J.E., Kerbauy, G.B. \& Monteiro, W.R. 2006. Desenvolvimento de protocormos de Catasetum pileatum Rchb.f. in vitro: aspectos estruturais e conceituais. Hoehnea 33(2): 177-184.

Manning, J.C. \& Van Staden, J. 1987. The development and mobilization of seed reserves in some African orchids. Australian Journal of Botany 35(3): 343-353

Manrique, J.P., Lizarazo, C.F. \& Silva, A.S. 2005. Evaluation of the effect of three growth regulators in the germination of Comparettia falcata seeds under in vitro conditions. In Vitro Cellular and Developmental Biology - Plant 41:838-843.

Martini, P.C., Willadino, L., Alves, G.D., Donato, V.M.T.S. 2001. Propagação da orquídea Gongora quinquenervis por semeadura in vitro. Pesquisa Agropecuária Brasileira 36(10): 1319-1324.

Moreira, B.M.T., Tomba E.E.C. \& Zonetti, P.C. 2007. Crescimento in vitro de plântulas da orquídea (Laelia Purpurata Lindl Var Venosa $\mathrm{X}$ Cattleya warneri $\mathrm{T}$. Moore alba) sob diferentes concentrações de sacarose e frutose. Revista Saúde e Biologia 2(2): 16-21.

Murashige, T. \& Skoog, F. 1962. A revised medium for rapid growth and bioassays with tobacco tissue cultures. Physiologia Plantarum 15(3): 473-497.

Myers, N., Mittermeier, R.A., Mittermeier, C.G., Fonseca, G.A.B. \& Kent, J. 2000. Biodiversity hotspots for conservation priorities. Nature 403:853-858.

Ponert, J., Figura, T., Vosolsobe, S., Lipavska, H., Vohnik, M. \& Jersakkova, J. 2013. Asymbiotic germination of mature seeds and protocorm development of Pseudorchis albida (Orchidaceae) are inhibited by nitrates even at extremely low concentrations. Botany 91(10): 662-670.

Rego-Oliveira, L.V. \& Faria, R.T. 2005. In vitro propagation of Brazilian orchids using traditional culture media and commercial fertilizers formulations. Acta Scientiarum Agronomy 27(1):1-5.

Rego-Oliveira, L.V., Faria, R.T., Fonseca, I.C.B. \& Saconato, C.H. 2003. Influência da fonte e concentração de carboidrato no crescimento vegetativo e enraizamento in vitro de Oncidium varicosum Lindl. (Orchidaceae). Semina: Ciências Agrárias 24(2): 265-272.

Rosas, M.M. \& Garcia, R.B. 2011. In vitro regeneration through direct organogenesis from protocorms of Oncidium tigrinum Llave \& Lex. (Orchidaceae), an endemic and threatened Mexican species. Hortscience 46(8): 1132-1135.

Roy, A.R., Patel, R.S., Patel, V.V., Sajeev, S. \& Deka, C. 2011. Asymbiotic seed germination, mass propagation and seedling development of Vanda coerulea Griff ex. Lindl. (Blue Vanda): an in vitro protocol for an endangered orchid. Scientia Horticulturae 128(3): 325-331.

Shiau, Y.J., Nalawade, S.M., Hsai, C.N. \& Tsay, H.S. 2005. Propagation of Haemaria discolor via in vitro seed germination. Biologia Plantarum 49(3): 341-346.

Soares, J.S., Rosa, Y.B.C.J., Suzuki, R.M., Scalon, S.P.Q. \& Rosa Junior, E.J. 2012. Germinação assimbiótica e desenvolvimento de Dendrobium nobile Lindl. sob efeito de reguladores vegetais no tratamento pré-germinativo. Revista Brasileira de Plantas Medicinais (14(4):617-623.

Sorace M.; Faria R.T.; Damasceno Junior C.V., Gomes G.P., Barbosa, C.M., Vieira F.G.N., Silva, G.L., Takahashi, L.S.A. \& Schnitzer. J.A. 2008. Crescimento in vitro de Oncidium baureri (Orquidaceae) em diferentes concentrações de macronutrientes e sacarose. Semina: Ciências Agrárias 29(4):775-782.

Souto, J.S., Morimoto, J.M., Ferreira, W.M., Nakabashi, M. \& Suzuki, R.M. 2010. Efeitos do ácido naftalenoacético no desenvolvimento in vitro de Cattleya bicolor Lindl. (Orchidaceae). Revista Brasileira de Biociências 8(2):179-185.

Spoerl, E. 1948. Amino acids as sources of nitrogen for orchid embryos. American Journal of Botany 35(2):88-95.

Stancato, G.C. \& Faria, R.T. 1996. In vitro growth and mineral nutrition of the lithophytic orchid Laelia cinnabarina Batem. (Orchidaceae). Lindleyana 11(1):41-43.

Stewart, J. 1989. Orchid propagation by tissue culture techniques - past, present and future. In Modern Methods in Orchid Conservation: the Role of Physiology, Ecology and Management (H.W. Pritchard, ed.). Cambridge University Press, Cambridge, p. 147-183. 
Stewart, S.L. \& Kane, M.E. 2006. Symbiotic seed germination of Habenaria macroceratitis (Orchidaceae), a rare Florida terrestrial orchid. Plant Cell Tissue and Organ Culture 86:159-167.

Stoutamire, W.P. 1964. Seeds and seedlings of native orchids. The Michigan Botanist, 3(4):107-119.

Suzuki, R.M., Moreira, V.C., Nakabashi, M. \& Ferreira, W.M. 2009. Estudos da germinação e crescimento in vitro de Hadrolaelia tenebrosa (Rolfe) Chiron \& V. P. Castro (Orchidaceae), uma espécie da flora brasileira ameaçada de extinção. Hoehnea 36(4):657-666.

Suzuki, R.M., Almeida, V., Pescador, R. \& Ferreira, W.M. 2010.
Germinação e crescimento in vitro de Cattleya bicolor Lindley (Orchidaceae). Hoehnea 37(4):731-742.

Suzuki, R.M., Moreira, V.C., Pescador R. \& Ferreira, W.M. 2012. Asymbiotic seed germination and in vitro seedling development of the threatened orchid Hoffmannseggella cinnabarina. In Vitro Cellular and Developmental Biology-Plant 48:500-511.

Taiz, L. \& Zeiger, E. 2002. Plant Physiology. Sinauer Associates Inc., Sunderland. $690 \mathrm{p}$.

Vacin, E.F. \& Went, F.W. 1949. Some pH changes in nutrient solutions. Botanical Gazette 110(4):605-617. 